\title{
HAKI PADA ERA INTERNET / ERA DIGITAL
}

\author{
INTAN RIZKA PRADANI \\ 155100039, 785567860 \\ Fakultas Komputer \\ intanrizkapradani.student@umitra.ac.id
}

\begin{abstract}
Kecanggihan teknologi kian hari kian meningkat. Peningkatan ini tidak terlepas dari hasil pengembangan ilmu pengetahuan dan teknologi. Khusus, pada bidang teknologi kemajuan teknologi tidak lepas juga dari proses inovasi. Hasilnya, saat ini telah hadir dihadapan masyarakat dunia teknologi terkini yang mampu menghubungkan antar umat manusia diseluruh dunia melalui jejaring antar komputer yang dikenal dengan internet.
\end{abstract}

Ketika kita berbicara tentang perlindungan hak cipta itu datang dalam pikiran kita bahwa secara umum diberikan kepada sastra asli, musik, drama atau karya artistik. Namun perkembangan teknologi baru telah menimbulkan konsep baru seperti program komputer, database komputer, layout komputer, berbagai bekerja pada web, dan lain-lain sehingga sangat perlu untuk tahu lebih banyak tentang hak cipta yang berkaitan dengan komputer program/software, database komputer dan berbagai pekerjaan dalam ruang cyber. Hak cipta isu kunci dalam hak kekayaan intelektual di era digital. Tulisan ini bertujuan untuk menunjukkan bahwa pekerjaan yang berkaitan dengan komputer dapat dilindungi di bawah hak cipta hukum

Teknologi internet yang menghubungkan antar satu komputer dengan komputer lainnya diseluruh dunia dengan memiliki daya kemampuan lintas batas negara dilewati secara mudah (bonderless world) telah melahirkan suatu era baru yang dikenal dengan era digital. Era digital ini ditandai dengan karakteristik berupa adanya kemudahan internaksi antar manusia di seluruh dunia dengan memanfaatkan jaringan internet dan tanpa terhalangi dengan wilayah geografis suatu negara dan aturanaturan yang sifatnya teritorial. Sejalan dengan itu juga, di era digital ini ditandai dengan karakteristik lainnya berupa adanya kemudahan setiap orang untuk memperoleh informasi. Informasi pada era ini sangat mudah diperoleh, dipertukarkan, diakses dan didistribusikan serta ditransmisikan kapan saja dan dimana saja.

Kata Kunci : paten pada era digital 


\section{A. INTRODUCTION}

Kecanggihan teknologi kian hari kian meningkat. Peningkatan ini tidak terlepas dari hasil pengembangan ilmu pengetahuan dan teknologi. Khusus, pada bidang teknologi kemajuan teknologi tidak lepas juga dari proses inovasi. Hasilnya, saat ini telah hadir dihadapan masyarakat dunia teknologi terkini yang mampu menghubungkan antar umat manusia diseluruh dunia melalui jejaring antar komputer yang dikenal dengan internet.

Ketika kita berbicara tentang perlindungan hak cipta itu datang dalam pikiran kita bahwa secara umum diberikan kepada sastra asli, musik, drama atau karya artistik. Namun perkembangan teknologi baru telah menimbulkan konsep baru seperti program komputer, database komputer, layout komputer, berbagai bekerja pada web, dan lain-lain sehingga sangat perlu untuk tahu lebih banyak tentang hak cipta yang berkaitan dengan komputer program/software, database komputer dan berbagai pekerjaan dalam ruang cyber. Hak cipta isu kunci dalam hak kekayaan intelektual di era digital. Tulisan ini bertujuan untuk menunjukkan bahwa pekerjaan yang berkaitan dengan komputer dapat dilindungi di bawah hak cipta hukum

Teknologi internet yang menghubungkan antar satu komputer dengan komputer lainnya diseluruh dunia dengan memiliki daya kemampuan lintas batas negara dilewati secara mudah (bonderless world) telah melahirkan suatu era baru yang dikenal dengan era digital. Era digital ini ditandai dengan karakteristik berupa adanya kemudahan internaksi antar manusia di seluruh dunia dengan memanfaatkan jaringan internet dan tanpa terhalangi dengan wilayah geografis suatu negara dan aturanaturan yang sifatnya teritorial. Sejalan dengan itu juga, di era digital ini ditandai dengan karakteristik lainnya berupa adanya kemudahan setiap orang untuk memperoleh informasi. Informasi pada era ini sangat mudah diperoleh, dipertukarkan, diakses dan didistribusikan serta ditransmisikan kapan saja dan dimana saja.

Dengan karakteristik era digital seperti di atas telah melahirkan suatu tantangan baru. Salah satu tantangan baru dalam bidang hukum ini dirasakan pada bidang hak cipta. Hak cipta sebagai sebuah konsep hukum yang melindungi karya-karya dalam bidang seni, sastra, dan ilmu pengetahuan dengan memberikan hak eksklusif telah mengalami suatu permasalahan yang kompleks. Jika melihat pada kompleksitas hak cipta di era digital, maka dapat diidentifikasi beberapa tantangan baru dalam bidang hak cipta.

Para pengguna media digital dapat dengan bebas menentukan konten di media tersebut. Internet memunginkan untuk adanya penyebaran informasi secara luas dan dapat dengan cepat diakses serta berbiaya murah yang langsung 
terhubung dengan sumbernya oleh pengguna tanpa perantara. Media digital bersifat fleksibel, sehingga memudahkan untuk memperbanyak, memodifikasi, Dalam konteks ini juga melalui digitalisasi konten sangat mudah untuk dilakukan manipulasi sehingga karya hasil manipulasi akan sulit dibedakan dari karya aslinya.

Dengan adanya tantangan di atas, dapat dipahami juga kehadiran media digital ini memberikan peluang terhadap lembahnya perlindungan hak cipta. Beberapa peluang lembahnya hak cipta dapat teridentifikasi dari karakteristik media internet yang berkaitan dengan hak cipta sebagai berikut:

1. Adanya kemudahan dalam melakukan reflikasi. Dalam konteks ini teknologi digunakan untuk menciptakan dan menggunakan karya digital yang dapat digunakan lagi untuk membuat salinannya secara terus menerus yang hampir mendekati kesempurnaan.

2. Adanya kemudahan dalam mentransmisikan dan menggunakannya secara terus menerus.

3. Melalui media digital pengguna dapat secara mudah memodifikasi dan mengadaptasi karya dalam bentuk digital.

4. Adanya sifat ekuivalen dari karyakarya dalam bentuk digital, semua karya sepertinya sama.

5. Adanya kepadatan karya-karya dalam bentuk digital-perpustakaan secara keseluruhan dapat disimpan.

6. Adanya penelusuran baru dan kemampuan untuk terhubung.

7. Kadang-kadang ketiadaan pengarang/pencipta.

Lemahnya perlindungan hak cipta ditimbulkan karena adanya suatu paham di sebagian kalangan masyarakat bahwa karya-karya digital di internet hakekatnya merupakan hak publik, di mana publik berhak untuk mendapatkan itu dan hal ini dilindungi oleh konvensi internasional tentang hak asasi manusia. Anggapan ini jelas pada akhirnya menimbulkan semakin lemahnya upaya memberikan perlindungan hak cipta atas karya digital.

Dalam UUHC Pasal 15 UUHC, antara lain disebutkan bahwa tidak merupakan pelanggaran hak cipta apabila penggunaan ciptaan pihak lain untuk kepentingan pendidikan, penelitian, penulisan karya ilmiah, penyusunan laporan, penulisan kritik atau tinjauan suatu masalah dengan tidak merugikan kepentingan yang wajar dari pencipta. Atau jika pengambilan ciptaan pihak lain itu guna keperluan pembelaan di dalam atau di luar pengadilan.

Perbanyakan suatu ciptaan secara terbatas dengan cara atau alat apa pun atau proses yang serupa oleh perpustakaan umum, lembaga ilmu pengetahuan atau pendidikan, dan pusat dokumentasi yang non-komersial semata-mata untuk keperluan aktivitasnya tidak pula dikategorikan pelanggaraan hak cipta. Namun memperbanyak untuk suatu program komputer merupakan suatu pelanggaran hak cipta. Pembuatan salinan cadangan (back-up copy) suatu program komputer oleh pemiliknya hanya dapat dilakukan semata-mata untuk digunakan sendiri.

$$
\text { Pelanggaran Hak Cipta }
$$
terhadap ciptaan berbasis teknologi digital di Indonesia dinyatakan dan 
diatur sanksinya dalam Pasal 72 ayat (1) UUHC yang menyatakan: "Barangsiapa dengan sengaja dan tanpa hak melakukan perbuatan sebagaimana dimaksud dalam Pasal 2 ayat (1) atau Pasal 49 ayat (1) dan ayat (2) dipidana dengan pidana penjara masing-masing paling singkat satu bulan dan/ denda paling sedikit Rp. 1.000.000 (satu juta rupiah) atau pidana penjara paling lama 7 (tujuh) tahun dan/ atau denda paling banyak Rp. 5.000.000.000 (lima miliar rupiah)".

Dalam Pasal 12 ayat (1) butir (d) UUHC, ciptaan yang dilindungi adalah ciptaan dalam bidang ilmu pengetahuan, seni, dan sastra, yang mencakup lagu atau musik dengan atau tanpa teks (salah satunya). Dalam kasus, berarti ciptaan yang dilindungi meliputi lagu / music yang diunduh oleh pengunduh. Namun tentu saja, pengunduh dapat dikatakan melakukan pelanggaran Hak Cipta adalah apabila memenuhi unsur-unsur pelanggaran Hak Cipta sebagaimana tersebut di atas dengan melakukan pengunduhan lagu-lagu melalui fasilitas internet. Apabila tidak memenuhi salah satu unsur saja, maka tidak dapat dikatakan bahwa pelaku telah melakukan pelanggaran Hak Cipta.

Dalam hal maraknya pelanggaran Hak Cipta karya digital penegak hukum haruslah bersikap tegas dalam menegakkan aturan dan peraturan hukum yang berlaku dan memberikan sanksi yang tepat bagi para pelanggar sesuai aturan hukum yang mengaturnya karena aturan dan peraturan dibuat bertujuan untuk memberikan perlindungan hukum bagi masyarakat luas.

\section{B. CONTENT}

Internet sebagai bagian dari era digital telah memberikan tantangan bagi HKI. Pasalnya, karya cipta manusia dapat dialihrupakan dalam bentuk digital yang kemudian perbanyakannya sangat mudah dilakukan.

Beberapa permasalahan HKI yang berkaitan dengan internet dalam era digital di antaranya berkaitan dengan masalah domain name, masalah tanggung jawab ISP (Internet Service Provider). Selain itu, beberapa hal teknis dalam pembuatan situs yang berpotensi untuk melanggar hak cipta, yakni deep linking, framing, dan inlining.

\section{ISP berisiko digugat}

ISP biasanya menyediakan layanan web hosting. Karena itu, ISP memiliki resiko untuk digugat oleh pemilik hak cipta yang merasa dilanggar haknya. Pasalnya, ada customer yang mem-posting material yang melanggar hak cipta dalam situs yang di-hosting di server milik ISP.

Sebagai ilustrasi, ada pihak yang mem-posting sebuah buku digital (digital book) dalam format PDF, yang jika dibeli dalam versi cetaknya mungkin saja seharga AS\$200. Jika kemudian buku ini di-download oleh dua puluh ribu pengunjung situs tersebut, jelas di sini betapa besar kerugian pencipta atau pengarang buku.

$\mathrm{Si}$ pengarang mungkin saja menuntut ISP karena buku 
karangannya telah diubah ke format digital. Namun, ISP mungkin saja telah memiliki penjanjian dengan customer-nya yang melarang si customer untuk mem-posting material yang melanggar hak cipta. Dan ISP tidak bertanggung jawab atas pelanggaran yang terjadi.

Toh, disclaimer semacam ini mungkin tidak cukup karena si pengarang tetap dapat menuntut pihak ISP. Misalnya dengan dalih, ISP telah memberikan suatu kontribusi tertentu bagi pelanggaran hak cipta atas karyanya.

Alasan pertama, karena pengarang kesulitan untuk menemukan orang yang mem-posting karya ciptanya tersebut. Apalagi sifat server ISP yang dapat diakses dari berbagai belahan dunia serta sifat anonimitas dari internet sendiri. Belum lagi, kewajiban bagi ISP untuk merahasiakan nama customer-nya.

Alasan kedua bagi pengarang untuk menuntut adalah masalah ekonomis semata. Pihak yang mem-posting tersebut belum tentu memiliki kemampuan keuangan yang cukup untuk membayar ganti rugi yang dimintakan. Sedangkan ISP sebagai entitas bisnis, dianggap dapat memberikan ganti rugi yang dimintakan.

\section{Melanggar hak cipta}

Sungguh sayang memang, padahal tentunya tidak ada kesengajaan dari pihak ISP untuk melakukan pelanggaran hak cipta. Namun jika memang ada semacam disclaimer dengan customernya, jelas pihak ISP telah memperkirakan kemungkinan adanya content situs yang di-hosting di server-nya yang melanggar hak cipta.
Screening atas isi content secara teknis memang dapat dilakukan. Namun seiring dengan perkembangan bisnis yang semakin besar, tentunya biaya dan sumber daya yang dibutuhkan akan semakin besar. Selain itu, juga waktu yang cukup lama dan secara bisnis justru akan memberatkan.

Kerjasama dengan pemilik karya cipta yang sangat umum dibajak mungkin salah satu alternatif yang bagus. Contohnya saja Microsoft, yang memiliki sistem tersendiri untuk melakukan scanning atas material/content di internet yang melanggar hak cipta atas software buatannya.

Jika ditemukan pelanggaran hak cipta, biasanya Microsoft akan meminta pihak di mana software bajakan di-posting untuk melakukan tindakan pemutusan atas service tersebut dan menghapus material tersebut dari server. Tiap harinya, konon Microsoft menemukan ribuan situs yang memuat software bajakan milik perusahaannya.

Contoh lainnya adalah lagu-lagu atau musik dengan format MP3. Coba saja Anda mencari lagu-lagu MP3 gratis di internet. Anda akan menemui beberapa broken link saat mendownload lagu tersebut. Hal ini menandakan pihak web hosting telah menghapus lagu tersebut setelah adanya screening ataupun complain dari pemilik hak cipta atas lagu.

Jika berhasil men-download, biasanya extension dari file MP3 harus diubah kembali ke MP3. Pengubahan extension file ini biasanya untuk mengecoh screening yang dilakukan oleh ISP ataupun 
jasa web hosting atas content situssitus di server milik mereka.

Mungkin pengaturan dalam Digital Millenium Copyright Act (DMCA) milik Amerika Serikat dapat dijadikan pelajaran yang baik. DMCA memberikan pembatasan masalah tanggung jawab ISP, dan penentuan kapan ISP bertanggung jawab atas materil yang di-hosting di server-nya atau sebaliknya, bilamana ia tidak bertanggung jawab.

\section{Aspek hukum linking}

Permasalahan hukum timbul karena content halaman web merupakan suatu karya cipta manusia yang mengandung beberapa komponen ciptaan, baik itu program komputer, lagu, seni rupa dalam segala bentuknya, fotografi dan sebagainya.

Berbagai ciptaan ini menurut ketentuan pasal 11 (1) UU No 12 Tahun 1997 tentang Hak Cipta merupakan ciptaan yang dilindungi. Sebagai suatu ciptaan yang dilindungi, pengumuman ataupun perbanyakan ciptaan tersebut tentunya haruslah seizin pencipta atau pemegang hak ciptanya.

Pembuatan linking saja tidaklah melanggar hak cipta. Namun jika kemudian halaman web yang dituju oleh link tersebut berisi content yang melanggar hak cipta, tentunya linking semacam ini memberikan kontribusi tersendiri bagi pelanggaran hak cipta.

Contoh yang menarik adalah berbagai situs penyedia file-file lagu dengan format MP3 yang halaman web-nya yang memberikan link-link ke situs penyedia file lagu-lagu ataupun musik dalam format MP3.
Situs-situs ini seharusnya patut diduga melanggar hak cipta.

Permasalahan lainnya dengan linking adalah kemungkinan pelanggaran merek dagang menimbulkan suatu dilusi. Akibatnya, value suatu merek dagang, khususnya famous and wellknown marks, akan menurun.

Teknologi web telah memungkinkan seorang webmaster dengan mudah menampilkan suatu merek dagang di halaman web-nya. Apakah itu berupa plain text, gambar, maupun karakter, serta kombinasi warna yang merupakan simbol merek dagang suatu produk ataupun jasa yang ada.

Pelanggaran merek dagang dan dilusinya terjadi karena besar kemungkinan pencantuman merek dagang ini akan menimbulkan persepsi bahwa suatu situs memiliki hubungan atau afiliasi dengan pemilik merek dagang yang ditampilkan.

Padahal sesuai ketentuan pasal 3 UU No 19 Tahun 1992, negara memberikan hak kepada pemilik merek untuk menggunakan sendiri merek tersebut atau memberikan izin kepada pihak lain untuk menggunakannya.

Selain persepsi yang timbul tersebut karena adanya penggunaan metatagging dalam pembuatan situs, ada pula kemungkinan penjelajah internet tertipu karena dibawa ke halaman web yang justru tidak memiliki keterkaitan sama sekali dengan merek dagang yang digunakan dalam metatagging.

\section{Deep linking dan inlining}


Perkembangan linking lebih lanjut berupa deep linking. Pengguna internet dapat mengunjungi suatu halaman dalam suatu situs tanpa melewati halaman depan (homepage).

Hal ini telah menimbulkan berbagai permasalahan tersendiri bagi kalangan e-business. Pasalnya, homepage bypassing seperti ini telah mengakibatkan hit rate situs menurun karena memang sering perhitungannya didasarkan atas jumlah pengunjung yang membuka halaman depan (homepage) situs.

Penurunan hit rate pada suatu situs sama dengan penurunan nilai situs. Pasalnya, akan mengakibatkan pihak sponsor tidak tertarik untuk memasang banner produknya di atau homepage yang sering dibypass.

Selain itu, sama dengan penggunaan merek sebagai link, ada kemungkinan pengunjung situs menganggap situs yang memberikan link tersebut memiliki hubungan tertentu dengan situs yang dituju.

Bentuk linking nonkonvensional lainnya adalah inlining. Bentuk ini memungkinkan webmasters secara otomatis menampilkan suatu graphic file, entah itu foto, kartun ataupun gambar lain dalam bentuk digital dalam webpage-nya yang berasal dari situs lain tanpa perlu memuatnya dalam situs yang dibuatnya.

Permasalahan pada inlining ini adalah gambar (graphic file) yang berasal dari situs lain tersebut dapat di-customized sedemikian rupa, sehingga tampilan yang diperoleh bisa saja berbeda dengan tampilan gambar pada situs asalnya.
Bila hal ini terjadi, maka jelas ada suatu modifikasi pada suatu karya cipta, yang tentunya melanggar hak si pencipta, baik itu hak atas pencipta atas karya turunan dari karya aslinya maupun hak moralnya atas karya cipta tersebut.

\section{Aspek hukum framing}

Teknik pembuatan situs lainnya adalah framing, di mana dengan penggunaan suatu frame, memungkinkan webmaster dapat menampilkan isi suatu situs lainnya tanpa meninggalkan situs yang memberikan frame tersebut.

Jadi seperti halnya frame pada fotofoto kita, frame tersebut akan selalu kita lihat saat memandang foto yang ada di dalamnya. Contoh lainnya mungkin mirip dengan fasilitas "picture in picture" pada beberapa merek televisi yang dapat menampilkan channel lainnya (dalam bentuk gambar yang lebih kecil) tanpa meninggalkan channel tv yang sedang kita tonton.

Contoh nyata situs yang sering menggunakan frame adalah web penyedia MP3. Pengunjung dapat melihat isi situs penyedia file MP3, sementara itu bagian dari situs tersebut tetap ada.

\section{Mendompleng nama}

Dalam beberapa kasus yang timbul berkaitan dengan framing ini, gugatan didasarkan pada beberapa hal. Pertama, framing dapat mengakibatkan perubahan penampilan suatu situs daripada yang seharusnya terlihat jika pengunjung langsung mengetikkan URL yang dituju. 
Dengan adanya framing memang harus diakui, alokasi tampilan di monitor komputer atas suatu situs berkurang karena adanya frame tersebut. Hal kedua yang menjadi dasar gugatan yakni pelanggaran merek dagang dengan menampilkan suatu merek tanpa adanya hak untuk itu.

Dasar gugatan selanjutnya adalah situs yang memberikan frame dianggap telah mendompleng nama dan keberhasilan situs lain serta mengambil manfaat ekonomi, berupa hit rate, dari situs yang diframe.

Dasar keempat dari gugatan adalah berkurangnya nilai ekonomis situs yang di-frame karena framing mengakibatkan banner ataupun iklan sponsor yang seharusnya tampak jika situs di-view secara langsung, justru tertimpa/tertutup oleh situs yang memberi frame.

Dasar gugatan selanjutnya adalah seringkali framing menyebabkan pengunjung situs tidak tahu nama situs yang sedang ditampilkan isinya tersebut. Akibatnya, pengunjung tidak dapat mem-bookmark-nya atau bahkan mengira situs yang diframe justru merupakan bagian dari situs yang memberi frame.

Selain itu, dari sisi hak cipta sendiri, perlu dikaji ulang apakah maksud dari pengumuman dan perbanyakan sesuai dengan ketentuan pasal 1 UU No 12 Tahun 1997 tentang Hak Cipta serta keterkaitannya dengan pemberian izin untuk kedua hal tersebut dalam konteks media internet.

Kajian ulang atas beberapa pengertian dalam hak cipta harus dilakukan dengan memperhatikan beberapa proses dan teknik di mana $w e b$ itu sendiri berjalan. Misalnya apakah framing dapat dianggap merupakan kegiatan memperbanyak atau menambah jumlah suatu ciptaan.

Permasalahan lainnya, apakah suatu media yang melakukan fiksasi atas karya cipta itu mempengaruhi pengertian perbanyakan. Hal ini patut dipertanyakan karena, saat melakukan surfing di internet, halaman web yang ditampilkan sebenarnya telah di-copy ke dalam memori komputer.

Posting suatu web page dapat dianggap suatu tindakan yang sesuai dengan pengertian pengumuman atas hak cipta sebagaimana diatur dalam pasal 1 angka 4 UU No 12 Tahun 1997. Pasal ini menyatakan bahwa pengumuman meliputi pembacaan, penyuaraan, penyiaran atau penyebaran suatu ciptaan, dengan menggunakan alat apapun dan dengan cara sedemikian rupa sehingga suatu ciptaan dapat dibaca, didengar atau dilihat oleh orang lain.

Dengan kata lain, pengumuman akan menyebabkan suatu ciptaan dapat diterima oleh indera manusia. Dalam konteks web, hal itu dapat berupa gambar, teks dan suara.

Lalu apakah proses framing sendiri merupakan suatu bentuk perbanyakan? Dalam prosesnya, situs yang menggunakan framing tidaklah melakukan perbanyakan suatu ciptaan, dalam hal ini isi web page yang di-frame.

Hal ini dikarenakan, saat pengunjung situs mengklik link situs target, server di mana situs target dihosting akan mengcopy web page yang diminta. Setelah itu, 
mengirimkannya ke terminal/komputer si pengunjung yang kemudian menampilkan web page yang dikirim tersebut. Berarti, perbanyakan justru terjadi antara server situs yang di-link dengan komputer pengunjung situs.

Ada pendapat yang mengemukakan, karena situs yang mem-frame tidak melakukan proses transfer ini, maka situs ini tidaklah melakukan perbanyakan. Akibatnya, tidak ada pelanggaran hak cipta yang terjadi secara langsung.

\section{CONCLUSION}

Kecanggihan teknologi kian hari kian meningkat. Peningkatan ini tidak terlepas dari hasil pengembangan ilmu pengetahuan dan teknologi. Khusus, pada bidang teknologi kemajuan teknologi tidak lepas juga dari proses inovasi. Hasilnya, saat ini telah hadir dihadapan masyarakat dunia teknologi terkini yang mampu menghubungkan antar umat manusia diseluruh dunia melalui jejaring antar komputer yang dikenal dengan internet.

Ketika kita berbicara tentang perlindungan hak cipta itu datang dalam pikiran kita bahwa secara umum diberikan kepada sastra asli, musik, drama atau karya artistik. Namun perkembangan teknologi baru telah menimbulkan konsep baru seperti program komputer, database komputer, layout komputer, berbagai bekerja pada web, dan lain-lain sehingga sangat perlu untuk tahu lebih banyak tentang hak cipta yang berkaitan dengan komputer program/software, database komputer dan berbagai pekerjaan dalam ruang cyber. Hak cipta isu kunci dalam hak kekayaan intelektual di era digital. Tulisan ini bertujuan untuk menunjukkan bahwa pekerjaan yang berkaitan dengan komputer dapat dilindungi di bawah hak cipta hukum

$$
\text { Pelanggaran Hak Cipta }
$$
terhadap ciptaan berbasis teknologi digital di Indonesia dinyatakan dan diatur sanksinya dalam Pasal 72 ayat (1) UUHC yang menyatakan: "Barangsiapa dengan sengaja dan tanpa hak melakukan perbuatan sebagaimana dimaksud dalam Pasal 2 ayat (1) atau Pasal 49 ayat (1) dan ayat (2) dipidana dengan pidana penjara masing-masing paling singkat satu bulan dan/ denda paling sedikit Rp. 
1.000.000 (satu juta rupiah) atau pidana penjara paling lama 7 (tujuh) tahun dan/ atau denda paling banyak Rp. 5.000.000.000 (lima miliar rupiah)".

Dalam Pasal 12 ayat (1) butir (d) UUHC, ciptaan yang dilindungi adalah ciptaan dalam bidang ilmu pengetahuan, seni, dan sastra, yang mencakup lagu atau musik dengan atau tanpa teks (salah satunya). Dalam kasus, berarti ciptaan yang dilindungi meliputi lagu / music yang diunduh oleh pengunduh. Namun tentu saja, pengunduh dapat dikatakan melakukan pelanggaran Hak Cipta adalah apabila memenuhi unsur-unsur pelanggaran Hak Cipta sebagaimana tersebut di atas dengan melakukan pengunduhan lagu-lagu melalui fasilitas internet. Apabila tidak memenuhi salah satu unsur saja, maka tidak dapat dikatakan bahwa pelaku telah melakukan pelanggaran Hak Cipta

\section{DISCUSSION}

Semakin canggihnya teknologi digital masa kini membuat perubahan besar terhadap dunia, lahirnya berbagai macam teknologi di era digital yang semakin maju telah banyak bermunculan. Teknologi pada era digital ini membawa banyak sekali manfaat dari berbagai bidang seperti politik, eknomi, sosial budaya, pertahanan atau keamanan serta teknologi informasi, sehingga tidak dipungkiri lagi setiap pemanfaatannya memiliki tantangan.

Teknologi internet yang menghubungkan antar satu komputer dengan komputer lainnya diseluruh dunia dengan memiliki daya kemampuan lintas batas negara dilewati secara mudah (bonderless world) telah melahirkan suatu era baru yang dikenal dengan era digital. Era digital ini ditandai dengan karakteristik berupa adanya kemudahan internaksi antar manusia di seluruh dunia dengan memanfaatkan jaringan internet dan tanpa terhalangi dengan wilayah geografis suatu negara dan aturan-aturan yang sifatnya teritorial. Sejalan dengan itu juga, di era digital ini ditandai dengan karakteristik lainnya berupa adanya kemudahan setiap orang untuk memperoleh informasi. Informasi pada era ini sangat mudah diperoleh, dipertukarkan, diakses dan didistribusikan serta ditransmisikan kapan saja dan dimana saja.

\section{E. REFERENCE}

[1] O. M. Febriani and A. S. Putra, "Sistem Informasi Monitoring Inventori Barang Pada Balai Riset Standardisasi Industri Bandar Lampung," J. Inform., vol. 13, no. 1, pp. 90-98, 2014.

[2] A. S. Putra, "Paperplain: Execution Fundamental Create 
Application With Borland Delphi 7.0 University Of Mitra Indonesia," 2018.

[3] A. S. Putra, "2018 Artikel Struktur Data, Audit Dan Jaringan Komputer," 2018.

[4] A. S. Putra, "ALIAS MANAGER USED IN DATABASE DESKTOP STUDI CASE DB DEMOS."

A. S. Putra, "COMPREHENSIVE SET OF PROFESSIONAL FOR DISTRIBUTE COMPUTING."

[6] A. S. Putra, "DATA ORIENTED RECOGNITION IN BORLAND DELPHI 7.0."

[7] A. S. Putra, "EMBARCADERO DELPHI XE 2 IN GPUPOWERED FIREMONKEY APPLICATION."

[8] A. S. Putra, "HAK ATAS KEKAYAAN INTELEKTUAL DALAM DUNIA TEKNOLOGY BERBASIS REVOLUSI INDUSTRI 4.0."

[9] A. S. Putra, "IMPLEMENTASI PERATURAN

PERUNDANGAN UU. NO 31 TAHUN 2000 TENTANG DESAIN INDUSTRI BERBASIS INFORMATION TECHNOLOGY."

[10] A. S. Putra, "IMPLEMENTATION OF PARADOX DBASE."

A S Putra "IMPLEMENTATION OF TRADE SECRET CASE STUDY SAMSUNG MOBILE PHONE."

[12] A. S. Putra, "IMPLEMENTATION PATENT FOR APPLICATION WEB BASED CASE STUDI
WWW. PUBLIKLAMPUNG. COM."

A. S. Putra, "IMPLEMENTATION SYSTEM FIRST TO INVENT IN DIGITALLY INDUSTRY."

[14] A. S. Putra, "MANUAL REPORT \& INTEGRATED DEVELOPMENT

ENVIRONMENT BORLAND DELPHI 7.0."

[15] A. S. Putra, "PATENT AS RELEVAN SUPPORT RESEARCH."

[16] A. S. Putra, "PATENT FOR RESEARCH STUDY CASE OF APPLE. Inc."

[17] A. S. Putra, "PATENT PROTECTION FOR APPLICATION INVENT."

[18] A. S. Putra, "QUICK REPORT IN PROPERTY PROGRAMMING."

[19] A. S. Putra, "REVIEW CIRCUIT LAYOUT COMPONENT

REQUIREMENT ON ASUS NOTEBOOK."

[20] A. S. Putra, "REVIEW TRADEMARK PATENT FOR INDUSTRIAL TECHNOLOGY BASED 4.0."

[21] A. S. Putra, "TOOLBAR COMPONENT PALLETTE IN OBJECT ORIENTED PROGRAMMING."

[22] A. S. Putra, "WORKING DIRECTORY SET FOR PARADOX 7."

[23] A. S. Putra, "ZQUERY CONNECTION

IMPLEMENTED

PROGRAMMING STUDI CASE PT. BANK BCA Tbk."

[24] A. S. Putra, D. R. Aryanti, and 
I. Hartati, "Metode SAW (Simple Additive Weighting) sebagai Sistem Pendukung Keputusan Guru Berprestasi (Studi Kasus: SMK Global Surya)," in Prosiding Seminar Nasional Darmajaya, 2018, vol. 1, no. 1, pp. 85-97.

[25] A. S. Putra and O. M. Febriani, "Knowledge Management Online Application in PDAM Lampung Province," in Prosiding International conference on Information Technology and Business (ICITB), 2018, pp. 181-187.

[26] A. S. Putra, O. M. Febriani, and B. Bachry, "Implementasi Genetic Fuzzy System Untuk Mengidentifikasi Hasil Curian Kendaraan Bermotor Di Polda Lampung," SIMADA (Jurnal Sist. Inf. dan Manaj. Basis Data), vol. 1, no. 1, pp. 21-30, 2018.

[27] A. S. Putra, H. Sukri, and K. Zuhri, "Sistem Monitoring Realtime Jaringan Irigasi Desa (JIDES) Dengan Konsep Jaringan Sensor Nirkabel," IJEIS (Indonesian J. Electron. Instrum. Syst., vol. 8, no. 2, pp. 221-232.

[28] D. P. Sari, O. M. Febriani, and A. S. Putra, "Perancangan Sistem Informasi SDM Berprestasi pada SD Global Surya," in Prosiding Seminar Nasional Darmajaya, 2018, vol. 1, no. 1, pp. 289-294. 